\section{Not so good when $75 \%$ of grant applications fail}

SIR - Your Editorial 'Never had it so good?' (Nature 447, 231; 2007) claims that British science is in "rather good shape". Those in British universities who apply for research grants might not fully agree.

In the case of the UK Biotechnology and Biological Sciences Research Council (BBSRC), the new Labour government in 1997 made more cash available. As a result, the success rate for grant applications went up to about $40 \%$ in $1998-2000$. Since then, however, there has been a steady decline to the present success rate of about $25 \%$, leaving $10-15 \%$ of applications rated of international quality but unfunded. During the same period, the number of applications to the BBSRC has increased from about 1,200 a year in 1998 to about 1,900 a year in 2005. This may reflect a decline in other sources of funding from bodies such as the Medical Research Council, or a preference among applicants for funders who, unlike charities, include an amount for overheads.

This situation is not good news for British science, in that about $75 \%$ of applications to the BBSRC are now rejected, representing a huge waste of effort and ideas.

One obvious solution is to put more money into the system, to increase the success rate among applications ranked as internationally competitive. Another suggestion is to change the system for submitting and assessing applications, placing more of the onus on the universities, perhaps via a quota system for applications. A third is to weight the system more in favour of applicants' published track record and less in favour of the proposed science (with a special track for first-time applicants).

Above all, let's try to do something about this crazy situation in which so many grant applications fail, with the result that so much time is wasted for applicants, reviewers and administrators.

Philip Strange

School of Pharmacy, PO Box 228, University of Reading, Whiteknights, Reading RG6 6AJ, UK

\section{Admission that intelligent design is a religious view}

SIR — The case of Guillermo Gonzalez being denied tenure at Iowa State University should figure prominently in court next time there is an attempt to introduce intelligent design into the school science curriculum. According to your News story (Nature 447, 364; 2007), Gonzalez, as a proponent of intelligent design, is appealing against the decision on the grounds that his application was rejected because of his religious beliefs, rather than his science. Is there any better evidence that intelligent design, by the admission of its own supporters (when convenient), belongs in classes teaching religion, not science?

\section{H. A. Lessios}

Smithsonian Tropical Research Institute, Box 0843-03092, Balboa, Panama

\section{Terrorists are activists who renounce non-violence}

SIR - As faculty members whose research was affected severely by a 2001 firebomb attack by the Earth Liberation Front (ELF), we object to the assertion in your Editorial 'Unwise branding' (Nature 447, 353; 2007) that charging ELF arsonists with terrorism could amount to erecting an "unbreachable wall" to dialogue between them and scientists.

The ELF and its sister the Animal Liberation Front (ALF) use violence against civilian targets to further a political viewpoint: this is the definition of terrorism. Calling the ELF and ALF terrorist organizations is a simple statement of fact. There is no need to mince words in a vain effort to placate groups whose members, through a dangerous combination of wilful ignorance and willingness to enforce their world view 'by any means necessary', eschew reason in favour of senseless violence.

Some ELF and ALF apologists believe that 'property damage' (including destruction of research buildings at universities) does not qualify as terrorism. Perhaps the ELF statement from which we quote below will give those apologists a glimpse of the perspective shared by those of us whose names and addresses have been posted on ELF or ALF websites (which link to instructions on firebomb construction and deployment). After the firebombing of a US Forest Service laboratory in Pennsylvania in 2002, the ELF declared: "segments of this global revolutionary movement are no longer limiting their revolutionary potential by adhering to a flawed, inconsistent 'nonviolent' ideology. While innocent life will never be harmed in any action we undertake, where it is necessary, we will no longer hesitate to pick up the gun to implement justice, and provide the needed protection for our planet that decades of legal battles, pleading, protest, and economic sabotage have failed so drastically to achieve."

Simply put, ELF and ALF members are anti-science, anti-intellectual, anti-human fundamentalists - certain that they have privileged access to some universal truth, deaf to alternative arguments, blind to evidence and determined to intimidate those who disagree with them. They are selfrighteous in firebombing the very institutions (such as ours) that sponsor research and open discourse to understand and improve the state of the Earth for all its inhabitants. ELF and ALF terrorists have built the wall of naive, intolerant fundamentalism between themselves and us - only they can breach it. Rational people are, and always have been, waiting on the other side in the hope of receiving some form of communication other than a bomb or a bullet.

Sarah Reichard ${ }^{\star}$, Thomas M. Hinckley*,

H. D. Bradshaw, Jri

${ }^{\star}$ College of Forest Resources,

University of Washington

†Department of Biology,

University of Washington,

Seattle, Washington 98195, USA

\section{Activists: arson risks killing innocent people}

SIR - Your Editorial 'Unwise branding' (Nature 447, 353; 2007) is against equating animal-rights activism with terrorism. In it you state that "there is no such objective thing as a terrorist". This statement is yet another example of the moral blindness invading public discourse in the United Kingdom.

It is straightforward to define terrorism in an objective and legally egalitarian manner, for example by defining as a terrorist any person who uses violence to further his or her ideology, without taking into consideration the likelihood that innocent people may be injured, maimed or killed by such violent acts. Arson fuelled by ideology would certainly fit this definition of terrorism, and the animal-rights arsonists discussed in your Editorial were apparently not deterred by the possibility that people might be injured or killed in the fires they set.

Your second concern, regarding "who will be willing to publicly break bread with a terrorist, reformed or otherwise", is answered by current reality in Northern Ireland, South Africa and other places around the globe. Mike Fainzilber

Biological Chemistry, Weizmann Institute, Rehovot, 76100 Israel

\section{Activists: some walls are not meant to be breached}

SIR - Your Editorial 'Unwise branding' (Nature 447, 353; 2007) stated: "We should avoid building an unbreachable wall between criminal activists and their victims." Am I mistaken, then, in the purpose for incarceration of criminals after conviction? Beverly E. Barton

Department of Surgery, University of Medicine and Dentistry of New Jersey, 185 South Orange Avenue, Newark, New Jersey 07103, USA 